\title{
DEPOSITION OF BODILY CHEMICAL COMPONENTS IN THE CARCASS OF TILAPIA (Oreochromis sp.) STRAINS
}

\author{
Deposição de componentes químicos corporais na \\ carcaça de linhagens de tilápia (Oreochromis sp.)
}

\author{
Ivan Bezerra Allaman', Rafael Vilhena Reis Neto ${ }^{2}$, Rilke Tadeu Fonseca de Freitas ${ }^{3}$, \\ Priscila Vieira Rosa ${ }^{3}$, Aline de Assis Lago ${ }^{3}$, Adriano Carvalho Costa ${ }^{3}$
}

\begin{abstract}
The knowledge of how animals deposited chemical components as water, protein, fat and ash in the carcass is importance for the formulation of a balanced diet, allowing maximum performance with a low environmental impact. So, the study was carried out to evaluate the influence of different tilapia strains (Chitralada, Commercial, Red and Universidade Federal de Lavras [UFLA]) on the deposition of bodily chemical components in the carcass. The bodily components analyzed were water, protein, fat and ash. For the determination of the bodily chemical deposition curves by age, the exponential, Brody, logistic, Gompertz and von Bertalanffy models were adjusted. The Commercial and UFLA strains deposited water at a faster speed $(\mathrm{P}<0.05)$ compared with the remaining strains. As for protein, the Red strain had a lower estimated maturity weight (49.37 g), and was more precocious (202 days) with regard to maximum deposition in comparison to the other strains (Chitralada, UFLA and Commercial) in which there was an estimated maturity weight of $231.5 \mathrm{~g}$ and maximum depositionfor 337 days. There were no differences ( $\mathrm{P}>0.05)$ for the logistic model parameter between Red, UFLA and Commercial strains for fat, which presented a maximum fat deposition (0.23 g) at 310 days of age. Regarding ash deposition, the Commercial strain presented a higher maximum deposition ( $0.10 \mathrm{~g})$ at $337 \mathrm{days}$, occurring later than the other strains that presented maximum deposition $(0.033 \mathrm{~g})$ at 254 days of age. Thus, it was concluded that the genetic strains evaluated differ in chemical deposition curves of water, protein, fat and ash.
\end{abstract}

Index terms: Bodily components, nonlinear models, fish, growth.

\begin{abstract}
RESUMO
O conhecimento de como os animais depositam componentes químicos como água, proteína, gordura e cinzas na carcaça é importante para a formulação de uma dieta equilibrada, permitindo o máximo desempenho com baixo impacto ambiental. Logo, o trabalho foi conduzido, com o objetivo de avaliar a influência de diferentes linhagens de tilápia sobre a deposição de componentes químicos na carcaça. Os componentes corporais analisados foram água, proteína, gordura e cinzas. Para a determinação das curvas de deposição química corporal em função da idade foram ajustados os modelos exponencial, Brody, logístico, Gompertz e vonBertalanffy. Houve ajuste apenas do modelo exponencial para a água, tendo as linhagens UFLA e Comerciais as que depositaram numa velocidade mais rápida $(\mathrm{P}<0,05)$ em relação às demais linhagens. Quanto à proteína, a linhagem Vermelha foi a que teve menor peso à maturidade, estimado $(49,37 \mathrm{~g})$ e foi mais precoce quanto à deposição máxima em relação as outras linhagens (Chitralada, UFLA e Comercial), no qual obtiveram peso a maturidade estimada em 231,5g e deposição máxima aos 337 dias de idade. Não houve diferença (P>0,05) dos parâmetros do modelo logístico entre as linhagens Vermelha,UFLA e Comercial para extrato etéreo, sendo a deposição máxima (0,23 g) aos 310 dias de idade. Em relação à deposição de cinzas, a linhagem Comercial teve maior deposição máxima $(0,10 \mathrm{~g})$ e, aos 337 dias de idade, sendo mais tardia em relação as outras linhagens que obtiveram deposição máxima de 0,033 g, aos 254 dias de idade. Portanto, conclui-se que as linhagens genéticas avaliadas diferem quanto às curvas de deposição química de água, proteína, extrato etéreo e cinzas.
\end{abstract}

Termos para indexação: Composição corporal, modelos não-lineares, peixe, crescimento.

\section{INTRODUCTION}

Animal growth is characterized by hyperplasia (increase in cell number) and hypertrophy (increase in diameter of the cells), which may be affected by several factors such as species, environmental conditions, fish size, level of dietary protein and feed rate (Ogata; Shearer, 2000).
The hypertrophic growth varies with the rate of somatic growth in the different stages of life, caused mainly by the deposition of water, protein, fat and minerals, which alter cell size and hence the size of the animals.

In animals, protein deposition is directly related to growth; in fish this nutrient is extremely important since they use it more efficiently as an energy source when

\footnotetext{
${ }^{1}$ Universidade Estadual de Santa Cruz/UESC - Rodovia Jorge Amado - km 16 - Bairro Salobrinho - 45662-900 - Ilhéus - Bahia - BA - Brasil ivanalaman@gmail.com

2Universidade Estadual Paulista Júlio de Mesquita Filho/UNESP - 01049-010 - São Paulo - SP - Brasil

3Universidade Federal de Lavras/UFLA - 37200-000 - Lavras - MG - Brasil

Received in april 15, 2014 and approved in july 20, 2014
}

Ciênc. Agrotec., Lavras, v.38, n.5, p.487-496, set./out., 2014 
compared to carbohydrates and lipids; moreover, protein represents $65 \%$ to $70 \%$ of body weight in dry matter.

Currently, in Brazil some strains of tilapia are being marketed and distributed as genetically improved strains, with higher growth rates. Among these strains there are a few that stand out: the Chitralada - developed in Japan, improved in Thailand and imported to Brazil in 1966 (Zimmermann, 1999); a Commercial strain which is derived from the Genetically Improved Farmed Tilapia (GIFT) program, which was developed in the Philippines; and Red, which is a hybrid of different genetic compositions and is marketed as Saint Peter, Florida Red and Jamaica, among others.

There are several models in the literature that describe both animal and vegetal growth. Among these, the Exponential (Malthus, 1798), Logistic (Nelder, 1961), Gompertz (Gompertz, 1825), Brody (Brody, 1945) and von Bertalanffy (Bertalanffy, 1957) models are the most used.

Some studies with fish that compare weight and growth between strains (Herbing; Boutilier, 1996; Svasand et al., 1996; Santos et al., 2008) have already been performed, showing that the growth curves are different between strains. Thus, it is likely that the different bodily components also have different growth curves. However, there are no studies in the literature that demonstrate the growth form of these chemical constituents for different tilapia strains.

In chickens, Marcato et al. (2009) demonstrated that male Ross and Cob strains showed different rates in weight growth, which was probably the result of different rates of protein and fat deposition observed in this study for these strains. Working with laying birds, Neme et al. (2006) also found differences between strains with regard to deposition rates of water, protein, fat and ash.

Thus, studying deposition of bodily tissues as a function of age and growth is very important for understanding the growth and deposition of animal tissues, enabling the development of more suitable nutritional programs (Neme et al., 2006).

This study was performed to evaluate the influence of genetic strains on the deposition of water, protein, fat and ash in Nile tilapias carcasses as well as studying different nonlinear models.

\section{MATERIAL AND METHODS}

The experiment was performed at the Fish Culture Station at Universidade Federal de Lavras (UFLA), in Lavras, Minas Gerais, beginning in March and ending in December 2012. The experiment consisted of three seasons: fall (March to May), winter (June to August) and spring (September to early December).

The following strains of tilapia were assessed in this study: Chitralada, a genetically improved commercial strain (Commercial), a strain of red tilapia (Red) and a strain of Nile tilapia that have been kept in the UFLA fish culture department since 1970 (UFLA).

Initially, 500 fingerlings from an all-male population (treated with $17 \alpha$-methyltestosterone) were cultured separately in four $56 \mathrm{~m}^{3}$ masonry tanks, and fed twice daily with a commercial diet with nutrient levels according to the phase of life $(42 \%, 32 \%$ and $28 \%$ protein: for the nursery phase, 10 to $100 \mathrm{~g}$; for the growth phase, from 100 to $300 \mathrm{~g}$; and for the termination phase, 300 to $600 \mathrm{~g}$, respectively). The daily amount was provided in accordance with the biomass of the tanks, ranging from $7 \%$ in the first week to $4 \%$ in the last week. The initial and final stocking densities (disregarding the observed mortality in the period) were 8.92 and $5.36 \mathrm{fish} / \mathrm{m}^{3}$, respectively. Harvests were made monthly in each tank where the strains were located in order to adjust the different densities that could be due to losses through mortality (predation and other causes).

The oxygen content $(\mathrm{mg} / \mathrm{L})$ and water temperature $\left({ }^{\circ} \mathrm{C}\right)$ were measured using a portable digital oximeter; $\mathrm{pH}$ was measured with the help of a technical commercial kit. All measurements were performed daily in the morning (8 am) and afternoon ( $2 \mathrm{pm})$.

Every 30 days, 20 fish were collected from each strain. After a period of fasting for 48 hours, fish were killed by spinal section followed by bleeding of the gills. Four specimens were selected and gutted; the scales were removed and ground in a multiprocessor and then sent to laboratory analysis in accordance with the Association of Official Agriculture Chemistry (AOAC) (1998). The body components analyzed were water, protein, fat and ash. The chemical constituents, in percentages, were transformed into grams for regression adjustments.

For the determination of the bodily chemical deposition curves in relation to age, the Exponential, Brody, Logistic, Gompertz and von Bertalanffy models were adjusted (Table 1). The functions were evaluated and chosen by the adjusted coefficient of determination (Adjusted r2) and mean square error (MSE). The adjusted coefficient of determination was calculated as: $r 2_{\text {Adjusted }}=1-\left[\frac{(\mathrm{n}-\mathrm{i})(1-\mathrm{r} 2)}{n-p}\right]$ where $\mathrm{r} 2$ is the coefficient of determination, " $n$ " is the number of observations used to adjust the curve, " $p$ " is the number of function parameters, including the intercept and " $\mathrm{i}$ " is the adjustment of the intercept, valued at " 1 " when there, and " 0 " when there is no intercept in the function. 
Table 1-Nonlinear models are commonly used to describe animal growth and to determine the absolute deposition rate (ADR).

\begin{tabular}{lcc}
\hline Models & Equation & ADR \\
\hline Exponential* & $y=a e^{k t}$ & - \\
Brody & $y=A\left(1-B e^{-k t}\right)$ & $A B k e^{-k t}$ \\
von Bertalanffy & $y=A\left(1-B e^{-k t}\right)^{3}$ & $3 A B k e^{-k t}\left(1-B e^{-k t}\right)^{2}$ \\
Gompertz & $y=A e^{-B e^{-k t}}$ & $A B k e^{-k t} e^{-B e^{-k t}}$ \\
Logistic & $y=A\left(1+B e^{-k t}\right)^{-1}$ & $A B k e^{-k t}\left(1+B e^{-k t}\right)^{2}$ \\
\hline
\end{tabular}

*The parameter "a" in the exponential model represents the intersection point of the axis "y".

The adjustment of the data was performed using the method of weighted least squares by the inverse of the variance of different ages in different strains, which increased with increasing age.

The function "nls" of the package "stats" version 2.10.0 (R Development Core Team, 2011) was used to adjust the nonlinear models. With this function, the argument "weights" was used for the function to do the adjustment by means of weighted least squares by the inverse of the variance. The algorithm used by the function "nls" was the "Gauss-Newton", which is the default algorithm. The calculation to find the initial values of the parameters to be used in the function "nls" for the convergence of the models was calculated as Fox (2002).

The likelihood ratio test (LRT) was used to check the equality of parameters between the different models, as suggested by Regazziand Silva (2004), to determine whether a single curve would be adequate to describe the deposition of each chemical component, regardless of the strain. After defining the best model, the absolute deposition rate (ADR) was calculated for each chemical component and strain through the first order derivative of the model adjusted in relation to time $(\partial \mathrm{Y} / \partial \mathrm{t})$. The LRT test statistic (Equation 1)is given by:

$L=\left(\frac{\hat{\sigma}_{\Omega}^{2}}{\hat{\sigma}_{\omega}^{2}}\right)^{n / 2}$

where "n" is the number of observation, $\hat{\sigma}_{\Omega}^{2}$ is the maximum likelihood estimate $\sigma^{2}$ of without any restriction in the parameter space and $\sigma_{\omega}^{2}$ is the maximum likelihood estimate of $\sigma^{2}$ with linear constraints, in accordance with the following assumptions: $\mathrm{H}_{0}{ }^{1}$ - parameter space restricted by $\mathrm{A}_{\text {Chitralada }}=$ $\mathrm{A}_{\text {UFLA }}=\mathrm{A}_{\text {Commercial }}=\mathrm{A}_{\text {Red }} ; \mathrm{H}_{0}{ }^{2}$ - parameter space restricted by $\mathrm{B}_{\text {Chitralada }}=\mathrm{B}_{\mathrm{UFLA}}=\mathrm{B}_{\text {Commercial }}=\mathrm{B}_{\text {Red }} ; \mathrm{H}_{0}{ }^{3}$ - parameter space restricted by $\mathrm{k}_{\text {Chitralada }}=\mathrm{k}_{\text {UFLA }}=\mathrm{k}_{\text {Commercial }}=\mathrm{k}_{\text {Red }}$.

To evaluate the accumulation of the deposition of nutrients in each season, the area under the growth curve (AUGC) was calculated (Equation 2). The seasons evaluated were fall, winter and spring, comprising the ages from 85 to 150,150 to 238 and 238 to 328 days, respectively. The variable AUGC was determined according to Shanerand Finney (1977) as:

$$
\sum_{i=1}^{n} \frac{y_{i+1}+y_{i}}{2}\left[x_{i+1}-x_{i}\right]
$$

Where:

$\mathrm{y}_{\mathrm{i}}=$ is the chemical component, in grams, of the $i$-th observation;

$\mathrm{X}_{\mathrm{i}}=$ is the age (days) of the $i$-th observation;

$\mathrm{n}=$ is the total number of observations.

The AUGC variable was submitted to analysis of variance (ANOVA) in a $4 \times 3$ factorial scheme (strains $\mathrm{x}$ seasons) proceeded by the means comparison test.

All variables were tested for the assumptions of ANOVA and, when violated, the appropriate transformation was used. The analyses were performed by means of software R (R Development Core Team, 2011).

\section{RESULTS AND DISCUSSION}

For temperature, the average $\bar{x}$ and standard deviation (s) values in each seasons for each strain were respectively: fall $(\operatorname{Red}-\bar{x}=23.09, \mathrm{~s}=3.05$; Chitralada $-\bar{x}=23.19, \mathrm{~s}=$ 2.51; UFLA $-\bar{x}=23.31, \mathrm{~s}=2.27$; Commercial $-\bar{x}=23.5$, $\mathrm{s}=2.86)$, winter $(\operatorname{Red}-\bar{x}=18.45, \mathrm{~s}=1.7$; Chitralada $-\bar{x}=$ 19.93, $\mathrm{s}=1.45 ;$ UFLA $-\bar{x}=19.36, \mathrm{~s}=1.46$; Commercial $-\bar{x}=18.61, \mathrm{~s}=1.58)$ and spring $(\operatorname{Red}-\bar{x}=25.09, \mathrm{~s}=$ 1.96; Chitralada $-\bar{x}=25.06, \mathrm{~s}=1.97$; UFLA $-\bar{x}=24.16$, $\mathrm{s}=1.98$; Commercial $-\bar{x}=24.46, \mathrm{~s}=1.64$ ).

The average and standard deviation of weight as well as of the bodily chemical components of each strains at each age is showed in the table 2 .

There was adjustment or convergence only for the exponential model for all strains referring to the deposition of water (Table 3 ). 
Table 2 - Average of weight, water, protein, fat and ash of UFLA, Red, Commercial and Chitralada strains at each age.

\begin{tabular}{|c|c|c|c|c|c|}
\hline \multirow{2}{*}{ Age (days) } & \multicolumn{2}{|c|}{ Strains } & \multirow{2}{*}{ Age (days) } & \multicolumn{2}{|c|}{ Strains } \\
\hline & UFLA & Red & & Commercial & Chitralada \\
\hline \multicolumn{6}{|c|}{ Weight (g) } \\
\hline 85 & $23.23(2.86)$ & $35.5(4.44)$ & 86 & $39.92(1.9)$ & $32.31(3.59)$ \\
\hline 104 & $31.83(0.41)$ & $50.3(5.7)$ & 109 & $43.28(0.27)$ & $49.5(2.17)$ \\
\hline 127 & $53.62(4.53)$ & $64.75(9.75)$ & 132 & $92.5(16.21)$ & $53.88(5.53)$ \\
\hline 150 & $96.75(9.51)$ & $89.62(20.23)$ & 158 & $119.25(15.05)$ & $85(7.29)$ \\
\hline 176 & $115.25(19.59)$ & $107.75(23.08)$ & 184 & $121(9.53)$ & $83(11.88)$ \\
\hline 202 & $110.5(26.72)$ & $120.5(21.19)$ & 220 & $174(19.61)$ & $134.75(12.63)$ \\
\hline 238 & $149.75(2.55)$ & $156(26.22)$ & 254 & $318.75(40.9)$ & $284.5(71.86)$ \\
\hline 272 & $235.25(60.38)$ & $235.25(60.38)$ & 276 & $337.25(50.1)$ & $240(54.82)$ \\
\hline 294 & $370.75(27.61)$ & $236(21.45)$ & 310 & $538.75(39.94)$ & $334.5(48.91)$ \\
\hline 328 & $487.75(66.06)$ & $408.25(69.18)$ & 337 & $646.5(38.22)$ & $468.5(59.55)$ \\
\hline \multicolumn{6}{|c|}{ Water $(\%)$} \\
\hline 85 & $73.47(1.98)$ & $73.63(0.28)$ & 86 & $74.99(0.66)$ & $76.35(0.55)$ \\
\hline 104 & $73.9(0.91)$ & $73.69(0.52)$ & 109 & $74.7(1.11)$ & $76.34(0.9)$ \\
\hline 127 & $74.88(1.19)$ & $74.83(0.55)$ & 132 & $73.17(0.6)$ & $73.47(1.22)$ \\
\hline 150 & $74(0.45)$ & $72.47(0.35)$ & 158 & $73.47(1.1)$ & $72.33(0.55)$ \\
\hline 176 & $73.13(1.52)$ & 71.4(0.98) & 184 & $72.06(0.98)$ & $71.49(0.61)$ \\
\hline 202 & $71.78(0.99)$ & $70.14(0.67)$ & 220 & $70.89(0.57)$ & $72.33(1.23)$ \\
\hline 238 & $71.72(0.91)$ & $70.62(1.17)$ & 254 & $72.85(1.15)$ & $73.56(1.16)$ \\
\hline 272 & $72.89(4.07)$ & $71.34(1.28)$ & 276 & $71.47(1.08)$ & $70.09(2.2)$ \\
\hline 294 & $71.8(1.81)$ & $70.17(1.66)$ & 310 & $71.14(1.24)$ & $72.14(0.58)$ \\
\hline 328 & $70.7(3.01)$ & $70.23(1.8)$ & 337 & $71.13(0.43)$ & $70.7(0.45)$ \\
\hline \multicolumn{6}{|c|}{ Protein $(\%)$} \\
\hline 85 & $16.47(0.78)$ & $16.42(0.69)$ & 86 & $15.97(0.54)$ & $16.04(0.4)$ \\
\hline 104 & $17(0.86)$ & $16.93(0.6)$ & 109 & $15.22(0.44)$ & $15.18(0.3)$ \\
\hline 127 & $15.74(1.1)$ & $15.48(0.32)$ & 132 & $15.82(0.8)$ & $15.93(0.25)$ \\
\hline 150 & $16.21(0.44)$ & $16.83(0.6)$ & 158 & $16.39(0.65)$ & $16.57(0.28)$ \\
\hline 176 & $19.21(1.13)$ & $19.31(0.51)$ & 184 & $17.64(0.81)$ & $16.93(0.64)$ \\
\hline 202 & $18.74(0.96)$ & $19.15(0.95)$ & 220 & $17.78(0.55)$ & $18.82(1.65)$ \\
\hline 238 & $18.77(0.72)$ & $19.23(1.06)$ & 254 & $15.56(1.41)$ & $15.76(0.66)$ \\
\hline 272 & $15.6(0.34)$ & $16.54(0.93)$ & 276 & $14.68(0.4)$ & $16.06(1.17)$ \\
\hline 294 & $14.63(0.87)$ & $15.56(0.64)$ & 310 & $14.9(1.19)$ & $15.37(0.81)$ \\
\hline 328 & $15.91(0.5)$ & $15.32(0.69)$ & 337 & $13.61(1.57)$ & $15.2(1.14)$ \\
\hline \multicolumn{6}{|c|}{ Fat $(\%)$} \\
\hline 85 & $7.3(0.53)$ & $7.42(0.63)$ & 86 & $5.4(0.55)$ & $5.06(0.59)$ \\
\hline
\end{tabular}


Table 2 - Continued....

\begin{tabular}{|c|c|c|c|c|c|}
\hline \multirow{2}{*}{ Age (days) } & \multicolumn{2}{|c|}{ Strains } & \multirow{2}{*}{ Age (days) } & \multicolumn{2}{|c|}{ Strains } \\
\hline & UFLA & Red & & Commercial & Chitralada \\
\hline 104 & $5.72(0.93)$ & $6.38(0.42)$ & 109 & $6.15(0.62)$ & $5.7(0.44)$ \\
\hline 127 & $5.91(0.63)$ & $5.51(0.53)$ & 132 & $6.86(0.82)$ & $6.62(0.67)$ \\
\hline 150 & $6.35(0.46)$ & $7.37(0.63)$ & 158 & $6.38(0.76)$ & $7.16(0.54)$ \\
\hline 176 & $9.49(2.16)$ & $8.38(0.87)$ & 184 & $7.17(0.85)$ & $7.12(0.6)$ \\
\hline 202 & $6.18(0.85)$ & 7.97(0.96) & 220 & $8.59(0.92)$ & $6.79(1.18)$ \\
\hline 238 & $9.9(1.66)$ & $9.97(1.72)$ & 254 & $6.13(1.04)$ & $6.01(1.14)$ \\
\hline 272 & $6.22(0.78)$ & $7.44(0.55)$ & 276 & $7.56(0.91)$ & $8.7(1.32)$ \\
\hline 294 & $7.7(0.84)$ & $8.53(0.97)$ & 310 & $7.88(1.45)$ & $6.67(1.05)$ \\
\hline 328 & $8.85(1.93)$ & $8.51(0.96)$ & 337 & $7.14(1.17)$ & $8(0.77)$ \\
\hline \multicolumn{6}{|c|}{ Ash (\%) } \\
\hline 85 & $2.54(0.46)$ & $2.61(0.4)$ & 86 & $2.49(0.42)$ & $2.3(0.22)$ \\
\hline 104 & $2.66(0.5)$ & $2.36(0.42)$ & 109 & $2.45(0.47)$ & $2.65(0.4)$ \\
\hline 127 & $2.46(0.21)$ & $2.39(0.25)$ & 132 & $2.86(0.78)$ & $2.77(0.55)$ \\
\hline 150 & $3.19(0.71)$ & $3.09(0.42)$ & 158 & $2.64(0.38)$ & $3.27(0.43)$ \\
\hline 176 & $2.72(0.6)$ & $2.31(0.3)$ & 184 & $2.63(0.43)$ & $2.66(0.59)$ \\
\hline 202 & $2.78(0.68)$ & $2.39(0.57)$ & 220 & $2.31(0.3)$ & $2.55(0.46)$ \\
\hline 238 & $2.14(0.38)$ & $2.55(0.56)$ & 254 & $2.77(0.53)$ & $2.27(0.57)$ \\
\hline 272 & $2.12(0.63)$ & $2.28(0.57)$ & 276 & $2.26(0.47)$ & $2.15(0.48)$ \\
\hline 294 & $2.34(0.5)$ & $2.64(1.08)$ & 310 & $2.31(0.65)$ & $2.16(0.5)$ \\
\hline 328 & $1.82(0.79)$ & $1.69(0.6)$ & 337 & $2.2(0.67)$ & $1.85(0.42)$ \\
\hline
\end{tabular}

Numbers in parentheses indicate standard deviation.

Table 3 - Estimates of parameters "a" and "k", confidence interval (LWR: lower limit; UPR: upper limit), mean square error (MSE) and adjusted determination coefficient $\left(\mathrm{r}_{\text {Adjusted }}\right)$, of the exponential model for water variable.

\begin{tabular}{ccccccc}
\hline \multirow{2}{*}{ Strains } & \multirow{2}{*}{ Parameters } & \multirow{2}{*}{ Fitted } & \multicolumn{2}{c}{ Confidence interval } & \multirow{2}{*}{ MSE } & \multirow{2}{*}{ 2 $_{\text {Adjusted }}$} \\
\hline \multirow{2}{*}{ Red } & $\mathrm{a}$ & 14.46 & 13.083 & 15.837 & 1.452 & 0.99 \\
& $\mathrm{k}$ & 0.0085 & 0.0081 & 0.0089 & & \\
Chitralada & $\mathrm{a}$ & 12.36 & 11.440 & 13.284 & 1.921 & 0.99 \\
& $\mathrm{k}$ & 0.0096 & 0.0092 & 0.0100 & & \\
UFLA & $\mathrm{a}$ & 7.13 & 6.675 & 7.582 & 5.19 & 0.99 \\
& $\mathrm{k}$ & 0.0115 & 0.0112 & 0.0119 & & \\
Commercial & $\mathrm{a}$ & 9.19 & 8.773 & 9.605 & 3.903 & 0.99 \\
& $\mathrm{k}$ & 0.0118 & 0.0115 & 0.0121 & & \\
\hline
\end{tabular}


In the exponential model, the parameter "a" reflects the initial weight measured in different strains; the UFLA strain had a lower $(\mathrm{P}<0.01)$ estimate, followed by the Commercial, Chitralada and Red strains. As to the deposition rate of water, which in this case is equal to $1 / \mathrm{k}$, the Commercial and UFLA strains were very similar $(\mathrm{P}>0.05)$, and higher $(\mathrm{P}<0.05)$ compared to the Chitralada and Red strains, with the latter presenting the lowest value.

With regard to the intensity or accumulation of water deposition, the Commercial strain, regardless of the season, was higher $(\mathrm{P}<0.01)$ than the other strains (Figure 1). Next comes the Chitralada strain $(\mathrm{P}<0.01)$ that presented higher deposition of water than the Red strain in the winter and spring, but was similar to Red in the fall. The UFLA strain presented accumulated water deposition similar to Chitralada and Red in the spring and winter, respectively, but was below these in the fall.
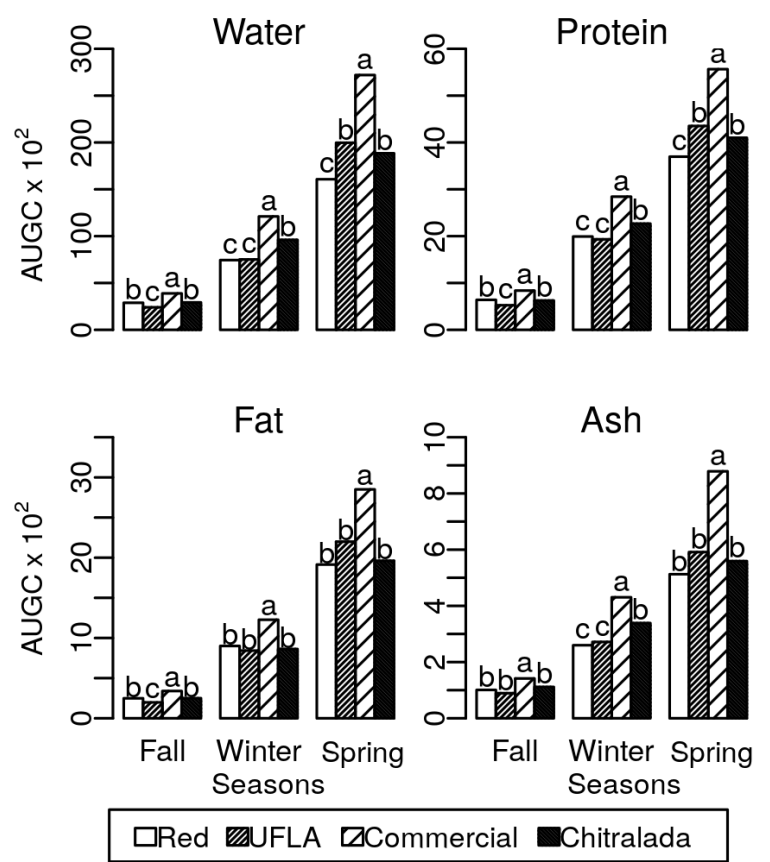

Figure 1 - Means of area under the growth curve (AUGC) of deposition of chemical components of each strain. Means followed by same letter between strains do not differ significantly $(\mathrm{P}<0.05)$ among themselves, by the Scott-Knott test.

The fact that the other models did not reach convergence is probably due to the fact that the animals had reached their maximum weight. It is likely that the age at maturity is similar to the maximum age of water deposition. Working with chickens, Marcato et al. (2009) observed that the age at maturity of body weight (on average 36 days) is close to the maximum age of water deposition (on average 34 days). In laying hens it was observed that the age at maturity is close to the age of occurrence of the maximum water deposition (55 days on average) (Neme et al., 2006).

Regarding protein deposition, among the models evaluated, only the exponential and logistic models adjusted, and the logistic model was the most adequate, as it presented a lower MSE value and higher $r 2$ value (Table 4). The Red strain presented a lower $(\mathrm{P}<0.01)$ estimate of the asymptotic weight (A) or maximum weight in relation to the other strains, which did not differ among themselves $(\mathrm{P}>0.05)$. The specific deposition rate $(\mathrm{k})$ was similar $(\mathrm{P}>0.05)$ among all strains. Thus, one model was adjusted to the Red Strain and another model was common to all other strains.

In the evaluation of protein deposition (Figure1), it was observed that protein deposition was higher for the Commercial strain, regardless of season, when compared to other strains. In the spring, UFLA and Chitralada strains presented protein deposition similar to, and higher than, the Red strain. In winter, the Red and UFLA strains showed deposition similar to, and lower than, the Chitralada strain. In the fall, the Red and Chitralada strains had deposition similar to, and higher than, the UFLA strain.

The protein deposition rate of the Chitralada, Commercial and UFLA strains was 30\% higher than the Red strain. However, the Red strain presented precocious maximum protein deposition at 202 days of age, while the other strains at 337 days of age (Figure 2). The maximum deposition rate at this age may be indicative of growth limitation due to several factors, mainly low water temperature, which suggests that Red is not a cold-tolerant strain. Watanabe et al. (1993) found that the sexually reversed Florida Red tilapia reached its best performance at $27{ }^{\circ} \mathrm{C}$. According to the results, it can be inferred that each strain has different nutritional requirements, which could direct the work of nutritionists in the formulation of diets for the strains under study, since protein deposition is controlled exclusively by genetics and, therefore, there is a limit to its daily deposition, regardless of the intake (Neme et al., 2006).

Concerning fat, the best adjusted model was the logistics one for the Red, UFLA and Commercial strains. When comparing the parameters " $A$ ", "B" and " $k$ " it was found that these strains did not differ $(\mathrm{P}>0.05)$, and the same model can be adjusted for all (Table 4). For the Chitralada strain, only the exponential model was adjusted, and it was not possible to compare this strain with the others. 
Table 4 - Estimates of parameters A, B and k, confidence interval (LWR: lower limit; UPR: upper limit), mean square error (MSE) and adjusted coefficient of determination $\left(\mathrm{r}_{\text {Adjusted }}\right.$, according to the models studied for the variables protein, fat and ash.

\begin{tabular}{|c|c|c|c|c|c|c|c|}
\hline \multirow{2}{*}{ Model } & \multirow{2}{*}{ Strains } & \multirow{2}{*}{ Parameters } & \multirow{2}{*}{ Fitted } & \multicolumn{2}{|c|}{ Confidence interval } & \multirow{2}{*}{ MSE } & \multirow{2}{*}{$\mathrm{r} 2_{\text {Adjusted }}$} \\
\hline & & & & LWR & UPR & & \\
\hline \multicolumn{8}{|c|}{ PROTEIN } \\
\hline \multirow{6}{*}{ Logistic } & \multirow{6}{*}{$\begin{array}{c}\text { (Chitralada, UFLA } \\
\text { and Commercial) }\end{array}$} & $\mathrm{A}$ & 49.369 & 40.221 & 58.517 & 1.309 & 0.99 \\
\hline & & $\mathrm{B}$ & 27.549 & 22.725 & 32.373 & \multirow{5}{*}{4.264} & \multirow{5}{*}{0.99} \\
\hline & & $\mathrm{k}$ & 0.016 & 0.013 & 0.018 & & \\
\hline & & A & 231.5 & 84.019 & 379.038 & & \\
\hline & & B & 131.9 & 56.763 & 207.020 & & \\
\hline & & $\mathrm{k}$ & 0.013 & 0.011 & 0.014 & & \\
\hline \multicolumn{8}{|c|}{ FAT } \\
\hline \multirow{2}{*}{ Exponential } & \multirow{2}{*}{ Chitralada } & $\mathrm{a}$ & 0.789 & 0.721 & 0.857 & \multirow[t]{2}{*}{1.507} & \multirow[t]{2}{*}{0.98} \\
\hline & & $\mathrm{k}$ & 87.401 & 83.852 & 90.951 & & \\
\hline \multirow{3}{*}{ Logistic } & \multirow{3}{*}{$\begin{array}{c}\text { (Red, UFLA and } \\
\text { Commercial) }\end{array}$} & A & 52.261 & 16.472 & 88.051 & \multirow[t]{3}{*}{1.408} & \multirow[t]{3}{*}{0.99} \\
\hline & & B & 60.459 & 30.763 & 90.154 & & \\
\hline & & $\mathrm{k}$ & 0.013 & 0.011 & 0.015 & & \\
\hline \multicolumn{8}{|c|}{ ASH } \\
\hline \multirow{6}{*}{ Logistic } & \multirow{3}{*}{ Commercial } & A & 30.816 & 5.891 & 55.741 & \multirow[t]{3}{*}{1.587} & \multirow[t]{3}{*}{0.93} \\
\hline & & $\mathrm{B}$ & 100.130 & 34.446 & 165.814 & & \\
\hline & & $\mathrm{k}$ & 0.013 & 0.011 & 0.015 & & \\
\hline & \multirow{3}{*}{$\begin{array}{c}\text { (Red, Chitralada and } \\
\text { UFLA) }\end{array}$} & A & 9.379 & 6.446 & 12.311 & \multirow[t]{3}{*}{1.76} & \multirow[t]{3}{*}{0.80} \\
\hline & & $\mathrm{B}$ & 37.05 & 28.844 & 45.248 & & \\
\hline & & $\mathrm{k}$ & 0.014 & 0.012 & 0.016 & & \\
\hline
\end{tabular}
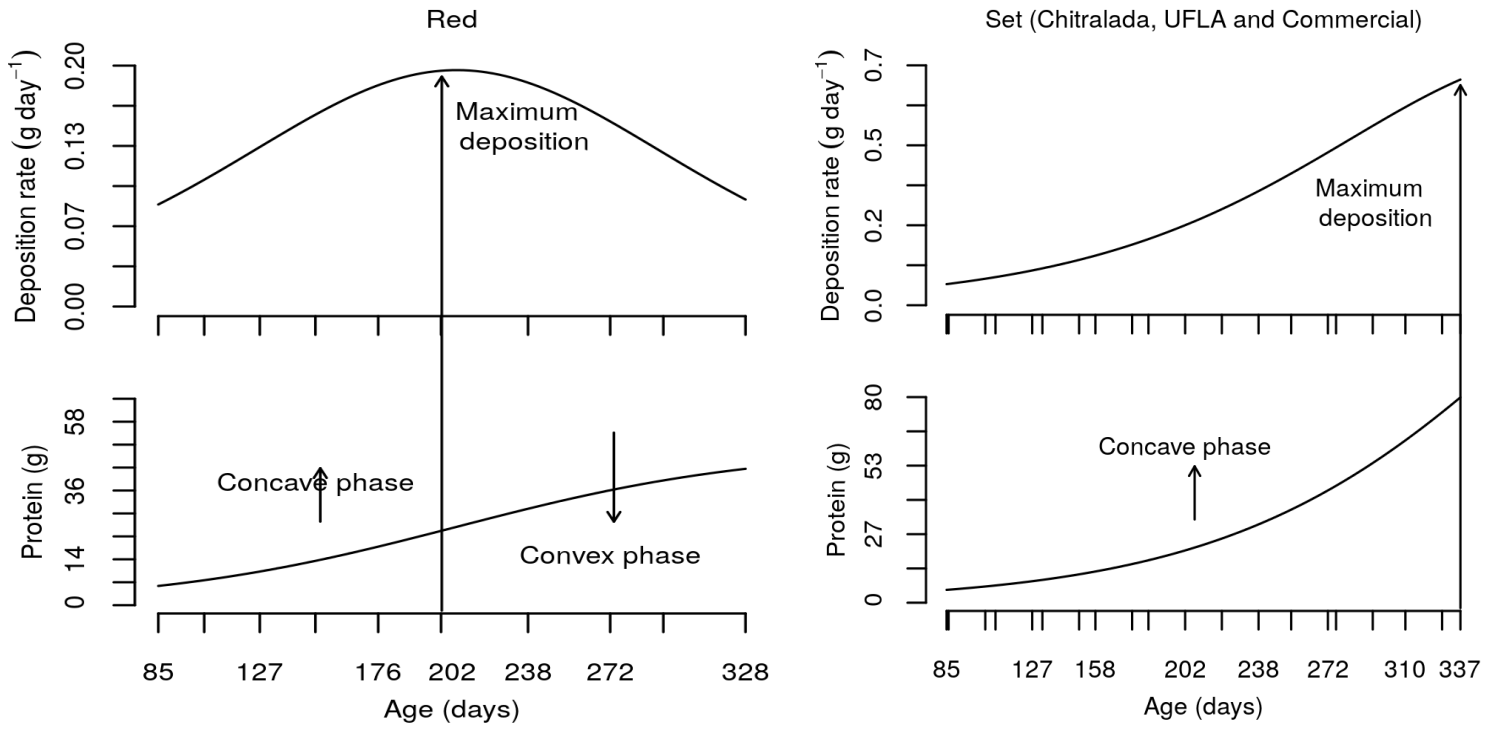

Figure 2 - Protein deposition rates and curves estimated by means of the logistic model with one equation for the Red strain and another equation for the Chitralada, UFLA and Commercial strains. 
By assessing the accumulation of deposition of bodily chemical components (Figure 1), it was observed that the Commercial strain was superior $(\mathrm{P}<0.05)$ to the other strains, for all seasons evaluated. In spring and winter the Red, UFLA and Chitralada strains had a similar deposition of fat. In the fall, similar to what occurred with the deposition of water and protein, UFLA was the strain with the lowest deposition of fat. It is likely that the higher fat deposition of the Commercial strain is related to the genetic selection to which it was submitted because, as noted by Thonneyand Ross (1987), in mice, genetic selection favoring protein development can result in rapid deposition of fat.

The maximum deposition rate of fat of the Red, UFLA and Commercial strains occurred at 310 days of age $(0.23 \mathrm{~g})$ (Figure 3$)$. This maximum deposition occurred 27 days before the maximum deposition of protein for the UFLA and Commercial strains, indicating that the deposition of fat of these strains reaches its peak earlier than the deposition of protein. However, the Red strain was the opposite, as the maximum deposition of fat of this strain occurred 108 days after maximum protein deposition.

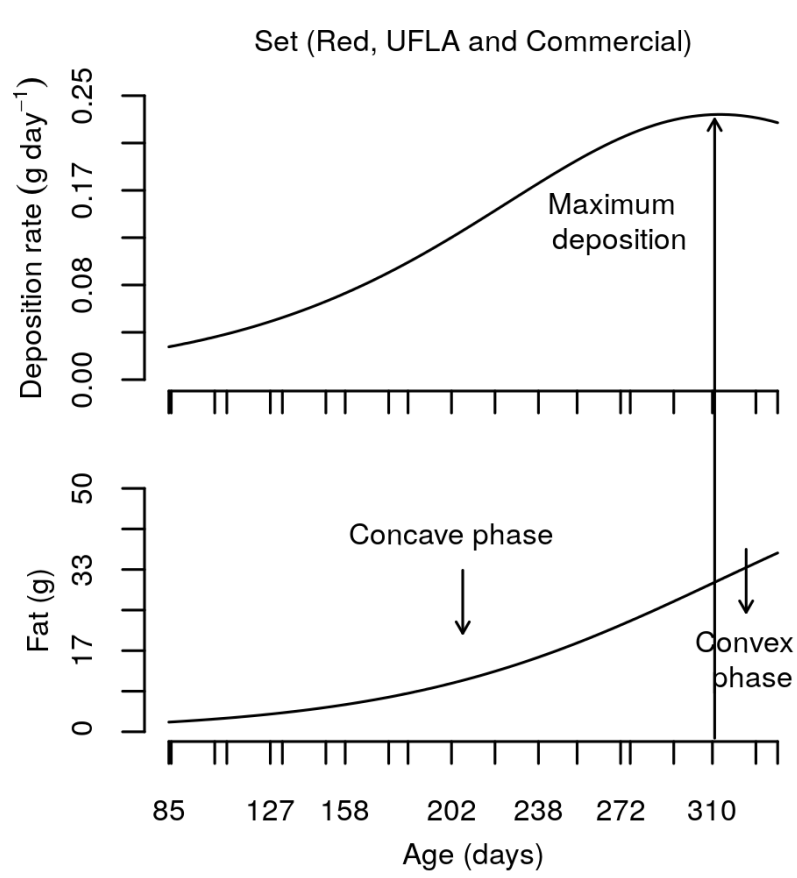

Figure 3 - Deposition rates and curves of fat estimated by the logistic model with a single equation for the Red, UFLA and Commercial strains.
For ash content, the best adjusted model for all strains was the logistic (Table 4). The maximum weight estimate for the Commercial strain was higher $(\mathrm{P}<0.05)$ than the Red, UFLA and Chitralada strains, with exception of the parameter " $\mathrm{k}$ " that did not differ $(\mathrm{P}>0.05)$ among the strains.

By observing the ash deposition (Figure 4), the Commercial strain obtained the highest mean in the three seasons. The Red, UFLA and Chitralada strains obtained similar mean deposition $(\mathrm{P}>0.05)$ in the fall and spring, and in the winter the Red and UFLA strains obtained deposition means similar to, and lower than, Chitralada.

The Red, Chitralada and UFLA strains were more premature with regard to the maximum deposition rate of ash (254 days) in relation to the Commercial strain (337 days) (Figure 4). Again, the Commercial strain obtained the highest maximum deposition rate, being 33\% higher than the other strains, a possible indication that this strain has higher calcium and phosphorus content (Silva; Queiroz, 2002).

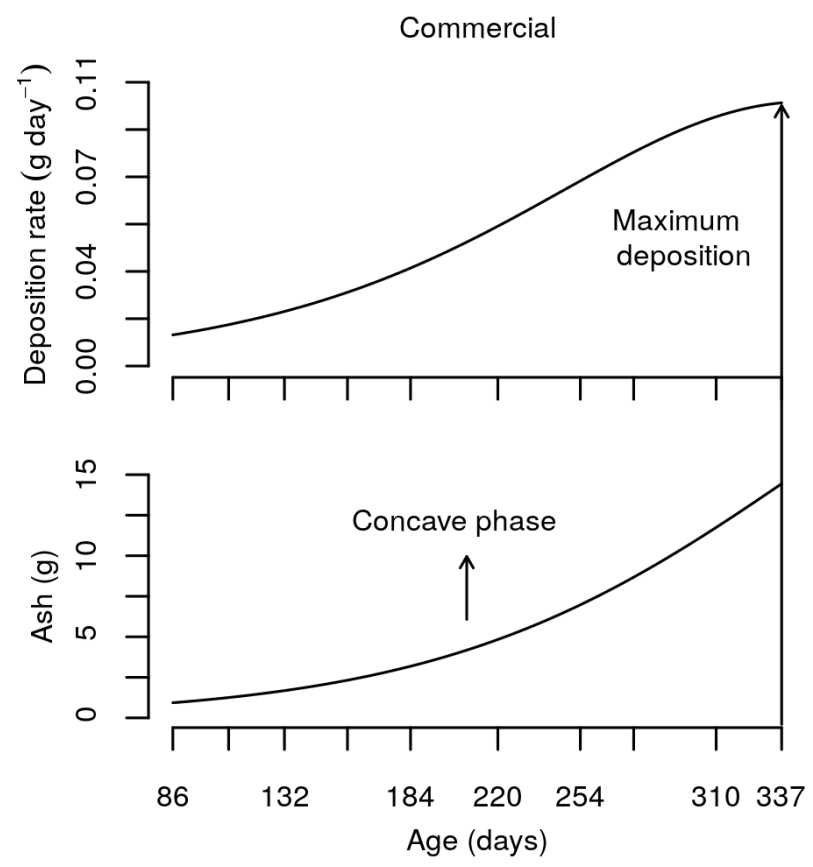

Figure 4 - Ash deposition rates and curves estimated by means of the logistic model with one equation for the Commercial strain and another equation for the Red, Chitralada and UFLA strains.

Continue... 


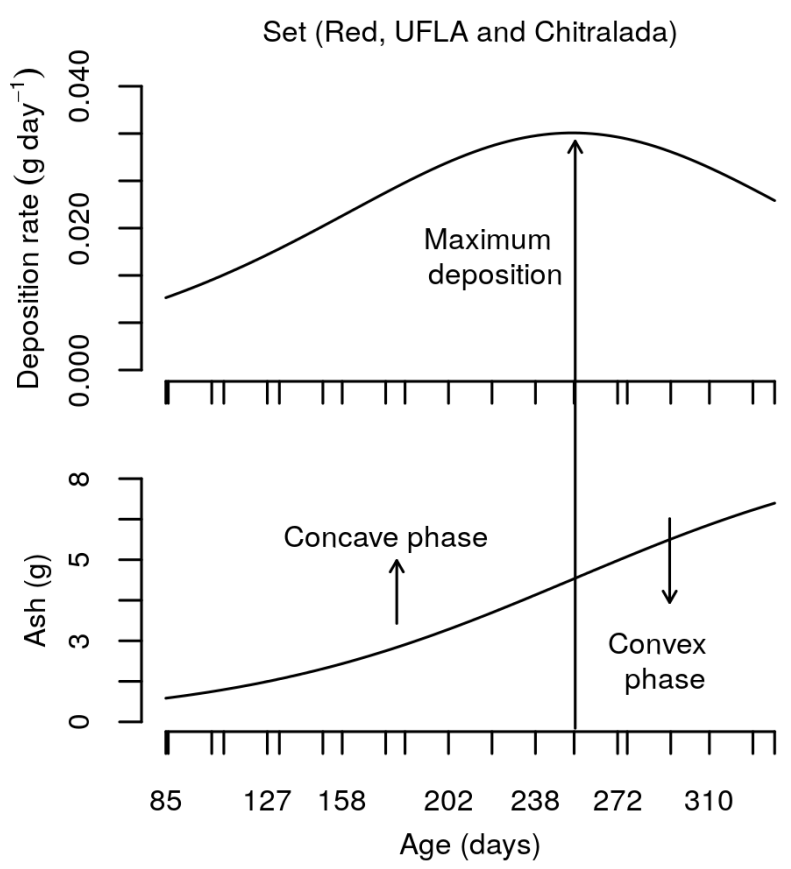

Figura 4 - Continued.

\section{CONCLUSIONS}

From the results obtained in this study, it can be concluded that the bodily deposition of water, protein, fat and ash is influenced by the different genetic strains of Nile tilapia, i.e. Red, UFLA, Chitralada and Commercial. The best model adjusted for water was the exponential regardless strain. For protein and ash constituents the best model was the logistic. For fat, the exponential model was the best fit for Chitralada strain and the logistic model for the other strains.

\section{REFERENCES}

OFFICIAL METHODS OF ANALYSIS-AOAC. Association of Official Analytical Chemists, Inc., Arlington, USA,16.ed., 1998, p.3-120

BERTALANFFY, L.V. Quantitative laws in metabolism and growth. Quarterly Review of Biology. 32(3):217$231,1957$.

BRODY, S. Bioenergetics and growth: with special reference to the efficiency complex of domestic animals. Hafner, New York, 1945, 1022 p.

FOX, J. An R and S-PLUS companion to applied Regression. SAGE Publications, 2002, 312 p.
GOMPERTZ, B. On the nature of the function expressive of the law of human mortality. Philosophical Transactions of the Royal Society. 36:513-585, 1825.

HERBING, L.H. V.; BOUTILIER, R.G. Activity and metabolism of larval Atlantic cod (Gadus morhua) from Scotian Shelf and Newfoundland source populations.

Marine Biology.124:607-617, 1996.

MALTHUS, T. An essay on the principle of population.J. Johnson, London, 1798, 273 p.

MARCATO, S.M. et al. Crescimento e deposição de nutrientes nas penas, músculo, ossos e pele de frangos de corte de duas linhagens comerciais. Ciência e Agrotecnologia. 33:159-1168, 2009.

NELDER, J.A. The fitting of a generalization of the logistic curve. Biometrics. 17:89-94, 1961.

NEME, R. et al. Curvas de crescimento e de deposição dos componentes corporais em aves de postura de diferentes linhagens. Revista Brasileira de Zootecnia. 35:1091-1100, 2006.

OGATA, H.; SHEARER, K. Influence of dietary fat and adiposity on feed intake of juvenile red sea bream Pargus major. Aquaculture.189:237-249, 2000.

R DEVELOPMENT CORE TEAM. R: Language and environment for statistical computing. Vienna: R Foundation for Statistical Computing, Vienna, Austria. Disponível em: http://www.R-project.org/. Acesso em: 10 jan. 2011.

REGAZZI, A.; SILVA, C. Teste para verificar a igualdade de parâmetros e a identidade de modelos de regressão não-linear: I. dados no delineamento inteiramente casualizado. Revista de Matemática e Estatística. 22:33-35, 2004.

SANTOS, V. et al. Exponential growth model of Nile tilapia (Oreochromis niloticus) strains considering heteroscedastic variance. Aquaculture. 274:96-100, 2008.

SHANER, G.; FINNEY, R. The effects of nitrogen fertilization on the expression of slow-mildewing in knox wheat. Phytopathology.70:1183-1186, 1977.

SILVA, D.; QUEIROZ, A. Análise de alimentos: Métodos químicos e biológicos. UFV, Viçosa, 2002, 235 p. 
SVASAND, T. et al. Differences in growth performance between Arcto-Norwegian and Norwegian coastal cod reared under identical conditions. Journal of Fish Biology. 49:108-119, 1996.

THONNEY, M.; ROSS, D. Composition of gain of rats fed low; high protein diets and grown at controlled rates from 80 to 205 grams. Journal of Nutrition.117:2135-2141, 1987.
WATANABE, W.O. et al. The effects of temperature and salinity on growth and feed utilization of juvenile, sex-reversed male Florida red tilapia cultured in a recirculating system. Aquaculture.112:309-320, 1993.

ZIMMERMANN, S. Um moderno instrumental genético no melhoramento e na rastreabilidade de tilápias nilóticas. Revista Panorama da Aquicultura.13:69-71, 1999. 